\title{
PATHOGENICITY OF SOME BACTERIAL SPECIES ISOLATED FROM THE BEE DIGESTIVE
} TRACT

\author{
DUGALIĆ VRNDIĆ NADA*, VUKOVIĆ V* and NEDIĆ N** \\ *Serbian Scientific Veterinary Institute, Belgrade, Serbia \\ ${ }^{\star *}$ Faculty of Agriculture, Zemun, Belgrade \\ (Received $5^{\text {th }}$ June 2009)
}

The aim of this paper was to examine the pathogenicity of most commonly isolated bacteria from the digestive tract of bees. Bees from 150 colonies $(n=3000)$ were examined and 19 bacterial species were isolated, which are either permanent or temporary inhabitants of the digestive tract. Pathogenic activity of the most commonly isolated species (Enterobacter aerogenes, Klebsiella ozaenae, Klebsiella pneumonie, Citrobacter freundii, Enterobacter cloacae and Enterobacter agglomerans) was examined on seven-day-old chicken embryos and tissue of MDBK cells. Bacterial inoculation of the examined bacteria was conducted in the alantoic cavity of chicken embryos in the quantity of $0.5 \mathrm{~mL}$. Control noninoculated and inoculated embryos were incubated at $38^{\circ} \mathrm{C}$ with about $60 \%$ relative humidity. All six bacterial species manifested pathogenic activity on chicken embryos and caused their death within 2-4 days and changes such as lagging in embryo development, bleeding and unpleasant smell. The bacteria examined in MDBK cell lines of bovine kidney tissue did not manifest cytopathogenic effect and the structure of control tissue was normal.

Key words: honey bee, intestines, bacteria, pathogenicity, chicken embryos, MDBK cells

\section{INTRODUCTION}

Composition of the digestive microflora of honey bees is the result of feeding pollen and nectar, but also it is a consequence of interaction among the bees in the hive (Glinski and Jarosz, 1995). In adult bees it consists of Grampositive, Gram-negative and Gram-variable bacteria, fungi and in some circumstances, yeasts.

Out of 19 bacterial species isolated from the bee's intestine only one belonged to anaerobic bacteria. The bacteria isolated were classified according to Bergey in 7 families and within them in 14 genera and 19 species. The most commonly isolated species were gram-negative bacteria identified by API E system: Enterobacter aerogenes, Klebsiella ozaenae, Klebsiella pneumonie, 
Citrobacter freundii, Enterobacter cloacae and Enterobacter agglomerans (Dugalić Vrndić, 1991; 1997). The researchers Gilliam (1987) and SmolskaSzymczewska (1989) isolated bacterial flora from bee intestine related to the following species: Bacillus, Enterobacter, Escherichia, Micrococcus, Staphylococcus, and Streptococcus, which matches with the findings of the author, but the most common bacterial species were not mentioned (Gilliam, 1987; Gilliam et al., 1988; Gilliam and Taber, 1991). In the investigation of Rada et al. (1997) anaerobic and aerobic microorganisms, lactobacilli, coliforms, staphylococci, Baccilus sp, and yeast were found in all examined bees. Jeremić et al. (2007) describe bacterial flora of the digestive tract of healthy young tilapia and carp bred in a polyculture. They isolated the following microorganisms: $E$. coli, Enterobacter, Seratia sp., Citrobacter, Proteus, Bacillus subtilis, Pseudomonas sp., Streptococcus and Aeromonas hydrophila which is pathogenic both for fish and humans. Almost identical bacterial flora of the digestive tract of healthy bees was noted by Dugalić Vrndić 1991; 1994; 1997). Sahay (2004) reports that Enterobacter aerogenes is part of healthy human and animal intestinal flora and it has been isolated from various products, soil, water and sewage. Bee's feces containing bacteria is not large in quantity, but can be found in orchards, vegetable gardens, water fields, springs and other places. Many animals and humans come into contact with bee feces in the nature, but they are not aware of it because of its small quantities. The bacteria isolated from the intestine can be pathogenic both for humans and animals. It is not well known how infectious intestinal bacteria are for humans and animals, but there is a possibility that they manifest their pathogenic activity and cause infections of both animals and humans. The examination of pathogenicity of the bacteria isolated from bee intestine was not conducted on the basis of available literary data, but author's data are used (Dugalić Vrndić, 1991).

\section{MATERIAL AND METHODS}

The individual inoculums were prepared from bacterial cultures isolated from bee intestine (Klebsiella ozaenae, Klebsiella pneumonie, Citrobacter freundii, Enterobacter cloacae, Enterobacter agglomerans and Enterobacter aerogenes), in the following way: Bacterial cultures were kept on oblique agar after isolation and identification, then they were reseeded from oblique agar to blood agar and have been incubated for 24 hours at $37^{\circ} \mathrm{C}$. In aseptic conditions, a suspension from the obtained cultures was made in distilled water, density was adjusted according to Mc Farland $\mathrm{N}^{\circ} 3$ and it was then homogenized by means of a centrifugal vibrator - vortex (Ašanin, 1979; 1980). The obtained homogenized suspension was then inoculated in three chicken embryos for each bacterial species examined. The embryos were 7 days old. Prior to inoculation embryonic eggs were examined and disinfected. They were inoculated to the alantoic cavity in a quantity of $0.5 \mathrm{~mL}$ - three embryos for each culture and one control which was not inoculated. After inoculation all the embryos were placed into an incubator at a temperature of $38^{\circ} \mathrm{C}$ with $60 \%$ humidity. The control was conducted every day by lamping during the period of four days. After the embryos died, they were opened 
and the changes were observed. Three MDBK containers were used for each culture and control tissue during the examinations on MDBK cell line of bovine kidney tissue. The cultures examined were reseeded from blood agar to nourishing beef tea which was incubated for six hours at $37^{\circ} \mathrm{C}$. The tissue with the cultures was incubated at $37^{\circ} \mathrm{C}$ and $\mathrm{CO}_{2}$ was added in a period of three consecutive days. Three days later, the changes were observed.

\section{RESULTS AND DISCUSSION}

The most commonly isolated bacterium from the intestine of bees was Klebsiella pneumonie. This bacterium is pathogenic both for humans and animals (Karakašević et al. 1989). Bergey (1984) and the following authors wrote about this bacterium isolated from the bee intestine: Dugalić Vrndić (1991; 1997), Lolin and Dugalić Vrndić (1994). It was interesting to examine the pathogenicity of Klebsielle pneumonie isolated from bee intestine, as well as other five bacterial species and observe what pathogenic changes these bacteria could cause. All the bacteria examined manifested pathogenicity on all chicken embryos and caused their death within two to four days (Dugalić Vrndić, 1991). Enterobacter cloacae caused death of embryos in the period of 2-3 days after inoculation, and diffusing hemorrhage all over the body.

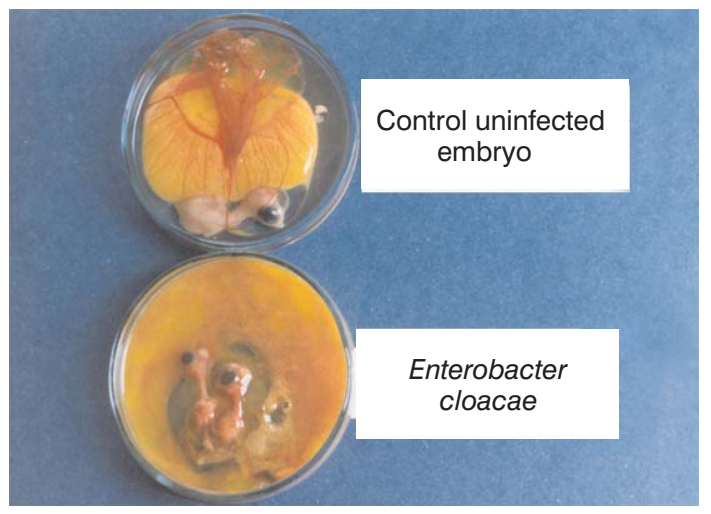

Figure 1. Pathogenic activity of bacterium Enterobacter cloace on chicken embryo

Lagging in development of embryos which can be easily decomposed by pincers is also evident. Alantochorion was necrotic and completely attached to the inner side of the egg-shell. This connection is not too strong and can be detached easily. The smell is unctuously unpleasant. Citrobacter freundii and Enterobacter aerogenes brought about the death of embryos on the second day after inoculation. There is visible lagging in growth of embryos. The whole of the embryo was bleeding and it was liable to decomposition when touched. The alantochorion was necrotic and completely attached to the inner side of the eggshell. This connection is not too strong, the smell is changed, unctuously 
unpleasant. Jeremić et al. (2003) report about bacterium Citrobacter freundii which caused gastroenteritis and high mortality in fish. Yu Min Chuange et al. (2006) notify that Citrobacter freundii induced necrotic fascilitis and osteomyelitis in patients treated with cefalotaxine. As these authors report this bacterium has a wide spectrum of pathogenicity both for animals and humans. Sahay (2004) and Fida (2004) wrote about Enterobacter aerogenes, as a cause of hospital infections in people.

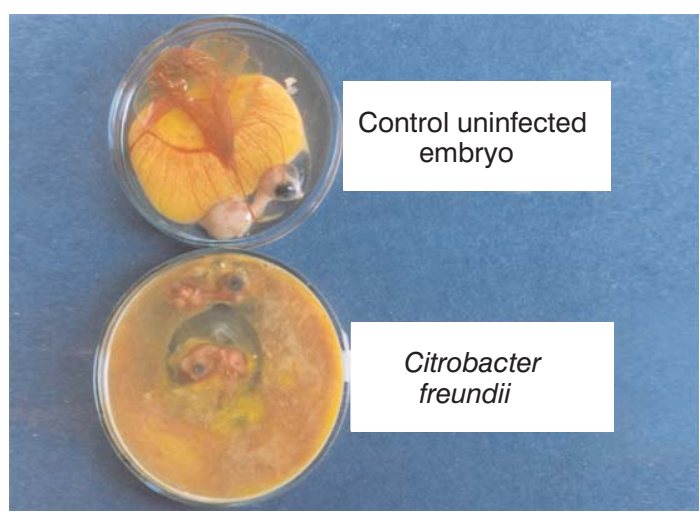

Figure 2. Pathogenic activity of bacterium Citrobacter freundii on chicken embryo

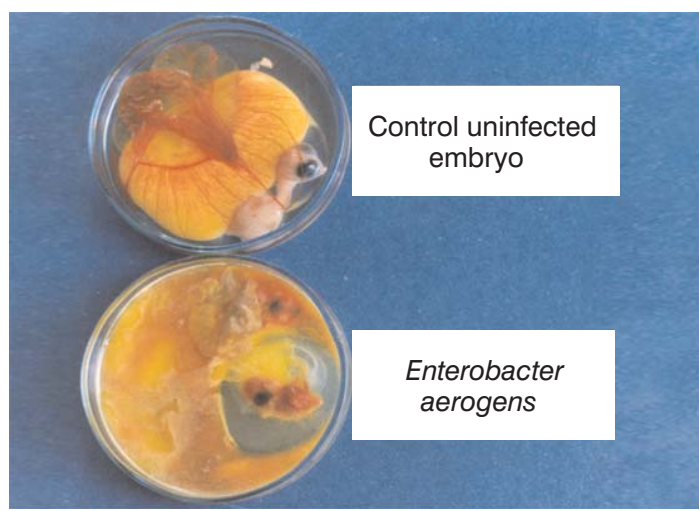

Figure 3. Pathogenic activity of bacterium Enterobacter aerogenes on chicken embryo

Enterobacter agglomerans caused death of embryos three days after inoculation. On the yolk sack, bleeding was evident on the body insertion. The yolk sack looks shrunken; it is light yellow, with blood initiated vessels. In comparison to control embryos, there was no lagging in growth. Dotted bleeding in the area of head and neck of the embryo was evident. The smell was changed and reminds of rotten organic matter. Fida (2004) writes about postoperative 
meninges infection, when Enterobacter agglomerans was isolated from the patients' cerebrospinal fluid. Parodi et al. (2003) during an eight-year study, described 15 post-neurosurgical cases of Enterobacter meningitidis and $E$. aerogenes being isolated from cerebrospinal fluid samples of $16 \%$ of the study population.

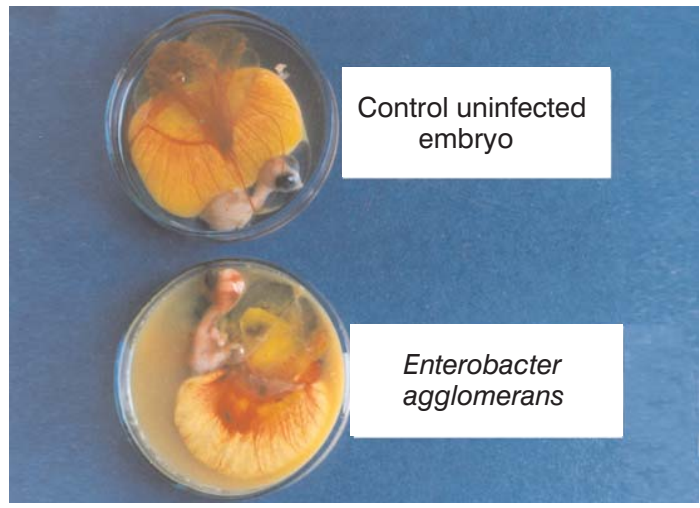

Figure 4. Pathogenic activity of bacterium Enterobacter agglomerans on chicken embryo

Klebsiella pneumoniae - due to its pathogenic activity, death of embryos occurred three days after inoculation. The embryo lags in development; it bleeds and easily decomposes during examination. Alantochorion is necrotic and loosely completely attached to the inner egg shell. The smell of the embryo is changed, and reminds of rotten organic matter. Parodi et al. (2003) in 20 neurosurgical patients isolated $E$. aerogenes from 9 samples of cerebrospinal fluid, E. cloacae from 6 and Klebsiella pneumonia in 1 sample. Enterobacter is normally found in the gastrointestinal region.

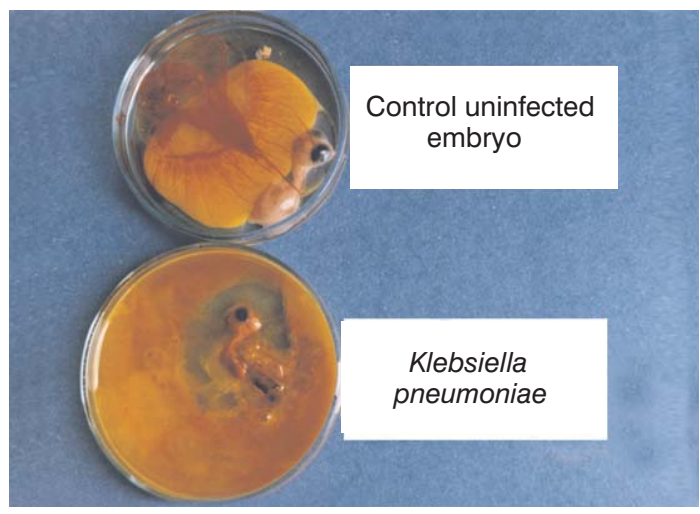

Figure 5. Pathogenic activity of bacterium Klebsielle pneumoniae 
Klebsiella ozaenae - death of the embryo due to the activity of this bacterium occurs 3-4 days after inoculation. Bleedings are discernable on the head and caudal part of embryo's trunk. The embryo developed properly in comparison to the control one. Blood vessels on the yolk sack are very initiated. Alantochorion is edematou and hemorrhagic (with a jelly-like consistency). The smell is unctuously unpleasant.

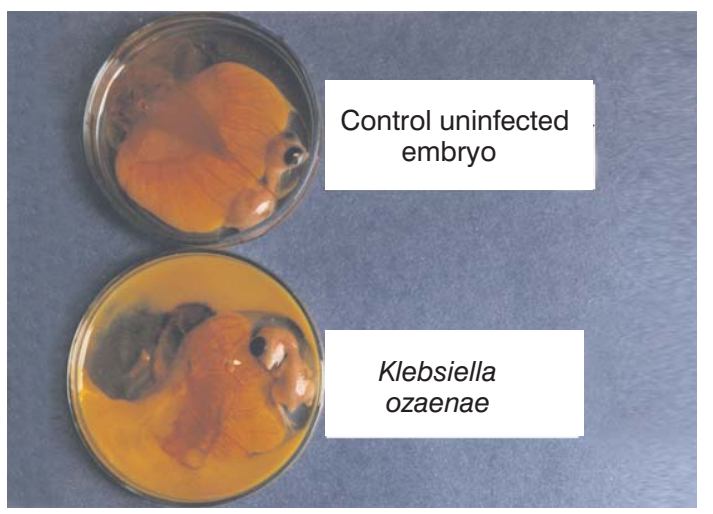

Figure 6. Pathogenic activity of bacterium Klebsiella ozaenae on chicken embryo

All 6 bacterial species isolated from honey bee's intestine as a normal microflora also represent normal intestinal flora in other animals and humans (Gilliam, 1987; Dugalić Vrndić, 1991; 1997; Smolska-Szymczewska, 1989; Jeremić et al., 2007; Parodi et al., 2003). These bacteria also exert pathogenic effects on animals and humans causing different infections and diseases, primarily when the immune system is impaired (Stuparević et al., 2007). Some bacterial species were the cause of death in animals and humans (Fida, 2004; Parodi et al., 2003; Jeremić et al., 2003).

Table 1 shows that bacteria Enterobacter aerogenes and Citrobacter freundii cause death of chicken embryos within the shortest period (2 days), followed by Enterobacter cloace (2-3 days), Enterobacter agglomerans and Klebsiella pneumonie (3 days), whereas Klebsiella ozene caused death of chicken embryos later on (3-4 days). The pathogenic activity of Enterobacter cloacae, Enterobacter aerogenes, Citrobacter freundii and Klebsiella pneumoniae causes lagging in growth of chicken embryos. Bacteria Enterobacter agglomerans and Klebsiella ozene do cause death without changes in their development. All the examined bacteria cause bleeding of chicken embryos, with certain differences in the intensity of bleeding. Diffused bleeding all over the body was caused by the following bacteria: Enterobacter cloacae, Enterobacter aerogenes, Citrobacter freundii and Klebsiella pneumoniae, i.e. the same bacterial species that caused lagging in growth of chicken embryos. Dotted bleeding on the head and neck was caused by Enterobacter agglomerans. Klebsiella ozene caused dotted bleeding on the head and back part of chicken embryos. Bacteria that caused dotted 
Acta Veterinaria (Beograd), Vol. 60, No. 1, 49-57, 2010.

bleeding and death of chicken embryos, did not cause lagging in growth. When dead chicken embryos which were exposed to the bacteria examined were opened, the smell was changed and was characterized as unctuously unpleasant for the following bacteria: Enterobacter cloacae, Enterobacter aerogenes, Citrobacter freundii and Klebsiella ozene. The smell of rottenness of organic matter with its pathogenic activity was caused by the following bacteria: Enterobacter agglomerans and Klebsiella pneumoniae (Dugalić Vrndić, 1991).

Table 1. The changes on chicken embryos due to pathogenic activity of bacteria isolated from bee intestine

\begin{tabular}{|c|l|c|c|c|c|}
\hline No. & $\begin{array}{c}\text { Type of } \\
\text { bacterium }\end{array}$ & $\begin{array}{c}\text { Death of } \\
\text { embryo }\end{array}$ & $\begin{array}{c}\text { Development } \\
\text { of embryo }\end{array}$ & $\begin{array}{c}\text { Bleeding on } \\
\text { embryo }\end{array}$ & SMELL \\
\hline \hline 1. & $\begin{array}{l}\text { Enterobacter } \\
\text { cloacae }\end{array}$ & $\begin{array}{c}\text { Between } \\
2-3 \text { days }\end{array}$ & Lagging in growth & $\begin{array}{c}\text { Diffuse, all over } \\
\text { the body }\end{array}$ & $\begin{array}{c}\text { Unctuously } \\
\text { unpleasant }\end{array}$ \\
\hline 2. & $\begin{array}{l}\text { Enterobacter } \\
\text { aerogenes }\end{array}$ & 2 days & Lagging in growth & $\begin{array}{c}\text { Diffuse, all over } \\
\text { the body }\end{array}$ & $\begin{array}{c}\text { Unctuously } \\
\text { unpleasant }\end{array}$ \\
\hline 3. & $\begin{array}{l}\text { Citrobacter } \\
\text { freundii }\end{array}$ & 2 days & Lagging in growth & $\begin{array}{c}\text { Diffuse, all over } \\
\text { the body }\end{array}$ & $\begin{array}{c}\text { Unctuously } \\
\text { unpleasant }\end{array}$ \\
\hline 4. & $\begin{array}{l}\text { Enterobacter } \\
\text { agglomerans }\end{array}$ & 3 days & Normal & $\begin{array}{c}\text { Dotted on head } \\
\text { and neck }\end{array}$ & Rotten smell \\
\hline 5. & $\begin{array}{l}\text { Klebsiella } \\
\text { pneumoniae }\end{array}$ & 3 days & Lagging in growth & $\begin{array}{c}\text { Diffuse, all over } \\
\text { the body }\end{array}$ & Rotten smell \\
\hline 6. & $\begin{array}{l}\text { Klebsiella } \\
\text { ozaenae }\end{array}$ & $3-4$ days & Normal & $\begin{array}{c}\text { Dotted on head } \\
\text { and back part }\end{array}$ & $\begin{array}{l}\text { Unctuously } \\
\text { unpleasant }\end{array}$ \\
\hline
\end{tabular}

Pathogenicity of the bacteria isloated from the bee intestine on MDBK cell line of bovine tissue did not manifest up to three days later and the structure of control tissue was normal. On the basis of the obtained results, MDBK cell line of bovine kidney tissue does not have any of the important characteristics needed for the examination of the cytopathogenic effect of these bacteria.

Address for correspondence:

Dr sci. med. Nada Dugalić Vrndić

Serbian Scientific Veterinary Institute, Belgrade

Autoput 3

11070 Novi Beograd, Serbia

E-mail: ndugalic@gmail.com

\section{REFERENCES}

1. Ašanin R, 1979, Ispitivanje citotoksičnih efekata filtrata hemolitičkih tipova E. coli, Vet Glasnik, 10, 767-71.

2. Ašanin $R, 1980$, Uporedna ispitivanja nekih tkivnih kultura u cilju određivanja citotoksičnih faktora E. Coli, Vet Glasnik, 12, 1123-6. 
3. Bergey's, 1984, Manual of Determinative Bacteriology, $8^{\circ}$ edition, Williams and Wilkins, Baltimore, Maryland, USA.

4. Dugalić Vrndić N, 1991, Proučavanje bakterijske flore digestivnog trakta Apis mellifica carnica, Određivanje patogenosti izolovanih bakterija i njihov značaj u epizootiologiji, Doktorska disertacija, Fakultet veterinarske medicine, Beograd.

5. Dugalić Vrndić N, 1997, A study of the microbial of bee intestine, Acta Veterinaria (Belgrade), 47, 23, 135-40.

6. Fida AK, 2004, Meningitis due to Enterobacter aerogenes subsequent to resection of an acoustic neuroma and abdominal fat graft to the masoid, Braz J Infect Dis, 8, 5.

7. Gilliam M, 1987, Microbial ecology of honey bees, The XXXI International Congress of Apiculture, Warsaw, Poland, 217-20, Apimondia, Publishing House, Bucharest, Romania.

8. Gilliam M, Taber S, 1991, Diseases, pests and normal microflora of honeybees (Apis mellifera) from feral colonies, J Invert Pathol, 58, 286-9.

9. Gilliam M, Lorenz BJ, Richardson GV, 1988, Digestive enzymes and microorganisms in honeybee (Apis mellifera): influence of streptomycin, age, season and pollen, Microbios, 55, 95-114.

10. Glinski Z, Jarosz J, 1995, Mechanical and biochemical defences of honey bee, Bee World, 76, 1108.

11. Jeremić S, Jakić Dimić D, Veljović $L j, 2003$, Citrobacter freundii as a cause of disease of fish, Acta veterinaria (Belgrade), 55, 5-6, 399-411.

12. Jeremić S, Radosavljević V, Ćirković M, Jakić Dimić D, 2007, Bakterijska flora digestivnog trakta mladih tilapija i šarana gajenih u mešovitim zajednicama, Savremena poljoprivreda, Novi Sad, $1-2$.

13. Karakašević $B$, 1989, Mikrobiologija i parazitologija, Medicinska knjiga, Beograd - Zagreb.

14. Lolin M, Dugalić Vrndić N, 1994, A study of bacterial flora of digestive tract of Apis mellifica and determination of pathogenicity of isloated bacteria and their importance in epizootiology, Review of papers - Yugoslav scientific meeting for beekeeping with international participatian, Sremski Karlovci, 76-7.

15. Parodi S, Lechner A, Osih R, 2003, Nososomial Enterobacter meningitis: Risk factors, management and treatment outcomes, CID, 37, 159-66.

16. Rada V, Machova M, Huk J, Marounek M, Duškova D, 1997, Microflora in the honeybee digestive tract: counts, characteristics and sensitivity to veterinary drugs, Apidiologie, 28, 357-65.

17. Sahay R, 2004, Entrobacter aerogenes, The IEQ Review, 1, 123.

18. Smolska-Szymczewska B, 1989, Influence De Quelquest chiemiotherapentiquest sur la flore intestinal de l' abeille mellifere, Apiacta, XXIV, 71-9.

19. Stuparević V, Bogicić S, Trokanović J, Žikić-Obradović T, 2007, Frequency of urinary infections in children in Negotin municipality in 2006. XXVI Timok medical days, Zajecar, 25-26. May 2007, Proceedings, 21-30.

20. Yu Min C, Sung Pin T, Lee-Jene T, Yu-Chi H, Po Rcu H, 2006, Emergence of cefalotoxine resistance in Citrobacter freundii causing necrotizing fascilitis and osteomyelitis, J Infect, 53, 3, 161-3. 


\title{
PATOGENOST NEKIH BAKTERIJSKIH VRSTA IZOLOVANIH IZ DIGESTIVNOG TRAKTA PČELE
}

\author{
DUGALIĆ VRNDIĆ NADA, VUKOVIĆ V i NEDIĆ N
}

\section{SADRŽAJ}

Cilj rada je bio da se ispita patogenost najčešće izolovanih bakterija iz digestivnog trakta pčele. Pregledano je 3000 pčela iz 150 pčelinjih zajednica, a izolovano je 19 bakterijskih vrsta, koje su stalni ili povremeni stanovnici digestivnog trakta pčela. Kod najčešće izolovanih vrsta (Enterobacter aerogenes, Klebsiella ozaenae, Klebsiella pneumonie, Citrobacter freundii, Enterobacter cloacae i Enterobacter agglomerans) ispitano je patogeno delovanje na kokošijim embrionima starim sedam dana i na kulturi tkiva MDBK ćelija. Bakterijska inokulacija ispitivanih bakterija izvršena je u alantoisnu šupljinu kokošijih embriona u količini od $0,5 \mathrm{ml}$. Kontrolni neinokulisani i inokulisani embrioni inkubirani su na $38^{\circ} \mathrm{C}$ sa oko $60 \%$ relativne vlažnosti. Svih šest bakterijskih vrsta ispoljilo je patogeno delovanje na kokošijim embrionima i dovelo do njihovog uginuća u roku od 2-4 dana sa promenama u vidu zaostajanja u razvoju embriona, prisutnim krvavljenjima i neprijatnom mirisu. Kod MDBK linije ćelija goveđeg bubrežnog tkiva ispitivane bakterije nisu ispoljile citopatogeni efekat, a kontrolno tkivo bilo je normalne strukture. 
